\title{
Upliftment of Rural Livelihood with Advanced Production Technology of Oyster Mushrooms
}

\author{
Vinita Rajput $^{*}$ and Ravika ${ }^{2}$ \\ ${ }^{1}$ Faculty of Agricultural Sciences, SGT University, Gurugram- Haryana, India \\ ${ }^{2}$ Department of Genetics \& Plant Breeding, CCS Haryana Agricultural University, \\ Hisar- Haryana, India \\ *Corresponding author
}

\section{A B S T R A C T}

Keywords

rural areas

natural calamities, pest attacks

Article Info

Accepted:

12 February 2020

Available Online:

10 March 2020
The economy of rural areas largely depends on agricultural practices. The livelihood is invariably affected with failure of crop due to natural calamities, pest attacks, poor intercultural practices, etc. Mushroom cultivation is rising as sustainable agriculture option for farmers, which is providing financial and nutritional securities to the population of rural areas. Among different cultivable mushroom species, oyster mushroom produces higher yields and earns more returns. With advanced production technology and research, the status of oysters can be uplifted in India. In the paper, recent advances in mushroom research have been reviewed which will helpful to focus on future aspects.

\section{Introduction}

Mushrooms are considered as gods' food and the miniature pharmaceutical factories. The use of mushrooms for food is known for hundreds of years. Out of thousands mushroom biodiversity present in nature, our ancestors, biologists and scientists have isolated approximately 100s of mushroom species that have a unique combination of nutrition that improve our health (Kalac, 2013; (Aida et al., 2009; Xu et al., 2011). While plants are autotrophs which make their own food through the process of photosynthesis, mushrooms are dependent on substrate material for the supply of nutrients to grow.

The vegetative mycelium (hypha network) absorbs nutrients, water, and necessary supplements and supplies fruiting bodies for their grow that reproductive stage (Oei, 2005; Ha et al., 2015). Majorly, fungi require carbon and nitrogen for mycelium growth and absorption of other nutrients such as iron, selenium, zinc, copper, manganese and 
molybdenum. Both micro and macro nutrients play role in growth, development and physiological functions of fungi viz. mushrooms (Chang and Miles, 2004). The commonly cultivated mushrooms are button mushrooms, oyster mushroom, paddy straw mushroom, milky mushroom, portobello mushroom and shiitake mushrooms.

Since ages, humans are consuming mushrooms, only in last two decades the commercial importance of these heavenly bodies have been identified. Due to higher nutritional values, excellent flavour and taste, mushrooms are added in gourmet dishes and menus at global level (Sheu et al., 2007; Mariga et al., 2014). The most popular mushrooms cultivated throughout the world were collected from wild by people whose nutritional value is known to them, whereas there are plenty of species of mushrooms in the biodiversity which are still unknown to the humankind. In some places, mushrooms are preferred over exotic vegetables and other dishes due to its fanciness.

\section{The oyster mushrooms}

In India, the major focus has been given on the production of button mushrooms, however, the productivity, yield potential, quality and medicinal aspects make oyster mushrooms more challenging. There are only a few species which can complete oysters in productivity and ease of cultivation. The oyster mushroom is a member of genus Pleurotus, commonly known as "Dhingri" in India.

It has got its name "oyster" from the resemblance of its fruiting bodies to sea oyster shells, that comes in different colours (white, cream, grey, pink and yellow).Some countries such as China, Italy and the USA are leaders in oyster mushroom production and China produces $85 \%$ of all (Pleurotus spp.) that is grown worldwide. Oyster mushrooms decompose plant and farm residues and absorb nutrients through its mycelial growth and reproduce spores for survival. During late fall to spring, often oyster mushrooms are found in form of cluster, hanging from the tree trunks as lignin degrader in forest areas, naturally. Wider adaptability has distributed these mushroom species to diverse climatic zones from temperate forests to subtropical zones. The biodiversity of oysters is limited in arid and semi-arid areas because of less relative humidity (Savoie et al., 2007).

All the varieties or species of oyster mushroom are edible except $P$. olearius and $P$. nidiformis, are considered not for human consumption as in researches presence of poisonous substance has been reported in these species. There are 38 species of the genus recorded throughout the world. In past years few species are domesticated in different countries viz.P ostreatus, $P$. flabellatus, $P$. florida, $P$. sajor-caju, $P$. sapidus, $P$. cystidiosus, $P$. eryngii, $P$. fossulatus, $P$. opuntiae, $P$. cornucopiae, $P$. yuccae, $P$. platypus, $P$. djamor, $P$ tuberregium, $P$. australis, $P$. populinus, $P$. levis, $P$ columbinus, $P$. membranaceus,etc.(Pe'rezMartı'nez et al., 2015; Knop et al., 2015; Zhang et al., 2016). Some of the Pleurotus species are reported to have carnivorous properties. These species attack on nematodes and digest them to obtain nitrogen for their growth and reproduction. It is a wellestablished fact that oysters not only can survive on flora residues but fauna residues also.

\section{History of cultivation}

During $19^{\text {th }}$ century, wooden $\operatorname{logs}$ and tree residues (on which oysters form fruiting bodies naturally) were used for growing Pleurotus species in Europe. The inoculated 
logs were kept under cool and moist environment to flourish mushrooms, naturally. After various trails, a German scientist Falck in 1917, successfully cultivated Pleurotus ostreatus in his experiments where he used wood logs and stumps as substrate materials. Mushrooms came out as an alternative to high energy food during the world war II, when food supply to people was the major concern.

Central Food Technological Research Institute (CFTRI), Mysuru pioneered mushroom cultivation in India in 1962 with $P$. flabellatus using paddy straw. Later, other substrates such as dried Euphorbia royleana stems for P. ostreatus (1970) and wheat and banana pseudo stems for P. sajor-caju(1974).

It was found from these research experiments that dried plant residues can be effectively used as substrate for growing different species of oyster mushrooms. Slowly, the commercial cultivation started at small scale by some researchers and innovative farmers.

\section{Global and national production status}

The oyster mushrooms are cultivated in United States of America, Asian countries (Thailand, Philippines, etc.), and European countries. After truffle and white button mushroom, oysters rank third in area coverage and production. More than $80 \%$ of the world's total oyster mushroom production is contributed by China.

The other countries producing oysters are Japan, South Korea and Taiwan.At present, the total mushroom production in India, including truffles, approximately 10, 000 tonnes. In India, the major producing states Bihar, Jharkhand, Uttar Pradesh, Orissa, Madhya Pradesh, Coastal Karnataka, Andhra Pradesh, Telangana, West Bengal and 7 states of north-east.

\section{Nutritional and medicinal properties}

People have been collecting them from the wild for ages and cultivating them as a valuable food. Oyster mushrooms are rich source of protein (1.6-2.5\%- fresh weight, 20$30 \%$ protein- dry weight), vitamin $\mathrm{C}$ and vitamin B complex, potassium, sodium, phosphorus, iron and calcium (Panjikkaran and Mathew, 2013; Kalac, 2009). The protein quality of oyster mushrooms is considered higher than that of fruits and vegetables. These mushrooms have immunity boosting, wound healing and antibodies stimulating properties. They also help in reducing tumours by retarding uncontrolled cell division in the tumour cell. Oyster mushrooms contain beta-1,3/1,6-glucan which stimulate the immune system and mevinolin which is important in lowering cholesterol level (Pathmashini et al., 2008; Yehia, 2012).

This species is also claimed to prevent high blood pressure, ease covering from fatigue, prevent hangover and prolong life. These mushrooms have been recognized as the alternate source of good quality protein which is higher than vegetables and fruits and is of high quality. They are reservoir of mineral, vitamins, proteins and health promoting compounds, therefore, its incorporation in routine diet provides complete nutrition. The discovery of bio-active compounds, including anti-tumour substances has stirred a growing interest in such mushrooms from industry, the media and the scientific community (Sheu et al., 2007; Mariga et al., 2014). A compound with antibodies like properties have been isolated from a species of oysters ( $P$. griseus) which is further under research for its effects on human health(Tikdari and Bolandnazar, 2012; Gume et al., 2013). Similar to phytoremediation, myco-remediation using oyster species is being implicated in industries.An alcohol named 'arabitol' which is a derivative of sugar fermentation, is found 
in small traces in oyster mushrooms depicting gastrointestinal problem reliving properties.

\section{Demand in international/ national market}

The oyster mushroom is used fresh, dried, canned or in powder form. It is an important ingredient of Japanese, Chinese and Korean Cuisine. It is also consumed in soups, stuffing, pickle and fried forms. In Odisha and Kerala(India),this mushroom is added to various vegetarian and non-vegetarian dishes. Although there is not great demand in national market, it is easy to sell the small produce by the growers. The international demand is so huge that it is difficult for small grower to meet. There is a need to develop a chain of producers so that the production from different farmers could be collected and supplied to international market as per export standards. With change in food dynamics, the demand for oyster mushrooms are increasing in gourmet food sector in India also. Moreover, people always try to use the most unique product of the market.

\section{Oyster mushroom production technology}

Cultivation of edible mushrooms is one of the most economically viable processes for the bioconversion of lingo-cellulosic wastes (Aguilar et al., 2010; Yehia, 2012). Pleurotus spp. can easily be grown by the rural women with minimum efforts. Dhingri is grown in northern plains from October to March when temperature ranges between $22-28^{\circ} \mathrm{C}$.Freshly prepared, good quality spawn is mixed with sterilized (chemically or with steam) chopped straw/ substrate (rice, wheat, barley, maize, etc.) under sterilized conditions. The mixture is filled in perforated polythene bags and kept in spawning room for completion of spawn run. After complete spawn run, the bags are shifted to cropping rooms. It takes approximately 20-30 days from spawn inoculation to first harvesting. Three to four flushes of crops can be taken from a single bag. Usually, hanging system is followed for cropping but shelf system is also followed by some big farmers as the latter increases capital investment.

Oyster mushroom cultivation does not require land or soil in acres to cultivate. The areas with problematic soils and adverse climatic conditions for open cultivation of crops can be effectively utilized for mushroom cultivation.

In comparison of other domesticated mushroom species, more yield per unit area is harvested in case of oyster mushrooms. The average productivity depends on the nutritional status of substrate and growing conditions. The substrate material with higher nitrogen percent can produce higher yield, therefore, sometimes the substrate is supplemented by addition of cotton seeds, oil cakes, pulse residues, etc. (Badu et al., 2011; Tesfaw et al., 2015). On an average, 500-700 $\mathrm{kg} /$ ton of substrate yield could be harvested in one cropping season that usually last for 12 months. It is much more than for button mushrooms with similar quality of substrate.

\section{Oysters changing rural livelihood}

High labour-land ratio and alarming rate of population growth may pose a threat to our food security in the very near future. The situation has led to a decrease in labour wages pushing the community below poverty line. Oyster mushroom cultivation is considered as an alternative source of income to uplift the living standards of poor farmers and also to add high quality protein in their daily diets to eradicate malnutrition problems. Mushroom cultivation can provide employment in both the semi-urban and rural areas. It is a way to uplift economic, social and nutritional status of rural people and their families as it provides employment opportunities in rural 
areas. Especially, women are benefited with mushroom culture (Gume et al., 2013; Ahmed et al., 2013), as women can work in mushroom units without affecting their routine household activities. Additionally, they do not need to go far from home to work and earn as the production unit can easily be established in the backyard of household.In India, mushroom cultivation till now not explored as per their potential. The state governments in many states contributing to farming community are providing trainings and starting material to promote mushroom farming. With technological improvements and innovation, the business of oyster mushroom production is expanding and generating good economic growth which is a great opportunity for farmers from rural areas. At the same time, it is also helping in management of poverty of small farmers through sustainable agricultural practices.

\section{Recent advances in oyster mushroom production technology}

\section{Substrate materials}

Oyster mushrooms grow on crop residues, agri-wastes which are called substrate Materials. Earlier only rice straw was used for growing oysters, but with increasing research and agri-wastes, other materials were also tried for spawning. The major waste materials used as substrate are cotton straw, bean straw, corncobs, cotton seed hulls, saw dust, rice straw, corn cob, paper waste, vegetable residue supplemented with rice bran, chicken manure, eucalyptus sawdust, eucalyptus bark, sugarcane bagasse, coffee husks, etc. (Hussain et al., 2002; Pant et al., 2006; Reddy et al., 2003; Li et al., 2001; Eira, 2003; Ragunathan and Swaminathan, 2003; Moda et al., 2005). These substrates are rich in biomass and mineral nutrition which are absorbed by mushroom hyphae and good quality fruit bodies are formed. The substrate can be used as single or in combination (Badu et al., 2011; Tesfaw et al., 2015). From scientific studies it is evident that combination of compatible substrates results in good yield (Yang et al., 2013; Zireva et al., 2007).Dhingri cultivation has been serving as potent solution to the burning of crop residue, a major concern related to environmental pollution.

\section{Substrate substitution}

The process of replacing rice/ wheat straw with any other plant residues, or plant material is known as substrate substitution. In various experiments, it as been observed that yield and quality of oyster mushrooms varies with nutrient status of substrate materials. The materials which are not sufficient to meet the requirement for good fruiting body development, needs to be supplemented with more nutritive and easily degradable substrates or agri-wastes (Estrada et al., 2009; Pardo-Giménez et al., 2012, 2016). The materials used for substitution are well rotten compost, seed husk of pulses, oil cakes, minerals, etc. It is also observed that composted and non-composted supplement materials affect yield, differently. In a study, olive waste from cultivar 'Alperujo' after oil extraction was used for supplementation (with or without composting) and the results showed that $20-40 \%$ substitution with rice straw material increased yield potential of Pleurotus spp. (Carrasco et al., 2018).Similar trials on substrate supplementation were conducted with husk of maize, oats, soybean and peanut shells, alone or in combinations. The protein content and quality in the harvested mushrooms was found higher (Rebecca et al., 2015). The rice straw substrate can be substituted partially or fully. The experiments with $100 \%$ substitution with sugar bagasse and corncob husk showed improvement in mineral, fibre and protein content of mushrooms (Ortega et al., 1992; Hoa et al., 2015). 


\section{Nutritional formulation}

The quality and production of oyster fruit bodies can further be enhanced with substrate amendments using nutritional formulations. The nutritional formulations are industrially manufactured compounds consisting organic proteins, vegetable meals, natural minerals, rice bran, vermi-wash, etc. which is being used for advanced production of mushrooms species. Commercially, various trade formulations are available in market for mushroom growers, to be used at different growth stages in case of button mushroom (spawning/ casing) and during substrate filling in bags in case of oyster mushroom (Zied et al., 2011; Burton et al., 2015).The protein, lipid, carboxylic acid and mineral based commercial products such as Amycel (Promycel ${ }^{\circledR}$, Titanium ${ }^{\circledR}$, Ultimate ${ }^{\circledR}$, etc.); Champfood, Lambert (Full House $\left.{ }^{\circledR}\right)$,etc.are very popular in market (Chang and Miles, 2004; Gil-Rami'rez, et al., 2013; Burton et al., 2015).

In European countries, wastes from cotton seed, poultry, food grain processing units, vineries, distilleries, nitrogenous and phosphate fertilizers are also identified as effective ingredients for substrate supplementation. Utilization of low-cost nutritional formulations increase harvest yield with minimum inputs (Zied et al., 2011; Pardo-Giménez, 2016). However, the addition of supplements results in rise in substrate temperature which later may lead to death of mushroom mycelium, it should also be controlled using mist or air-conditioning. For best results from supplementation, the availability of nutrients from substrate to mushroom mycelium should be at slower rates, to ensure proper degradation and assimilation of supplemented material into substrate. Researches have shown positive effects of formaldehyde treatments on reduced nutrient supply rates. It is assumed that formaldehyde denatures the proteins and limit the supply of nutrients. The treatment also inhibits growth of other fungi in the growing bags during spawning making the fungi of interest stronger (Carrol and Schisler, 1976). It is evident from recent studies that if favourable conditions are maintained and compatible formulations are used with substrate materials, the performance of oyster species can be enhanced to increase total yield.

\section{Mushroom growth promoting microbes}

With advanced research technology, the role of microorganisms has been recognized in promotion of mushroom growth. There are some microorganisms which are proved to have a positive effect on oyster spawning and fruiting. The bacteria genera including Bacillus, Pseudomonas, Azotobacter, etc. supports mycelial growth and fruiting bodies development of oyster mushrooms, besides these bacteria also slows growth of competitive fungi and moulds, serving as an alternate for supplementation. However, knowledge of compatible strains, extent of culture, and handling is important factors in successful supplementation as biofertilizers (Jadhav et al., 2014; Pratiksha et al., 2017).

\section{Utilization Spent mushroom substrate (SMS)}

Oyster mushroom cultivation is successfully managing the crop residue problem, but a lot of used substrate after harvesting mushrooms is generated, annually approximately 200 billion $\mathrm{kg}$ of spent mushroom substrate is derived, which is enriched with proteinaceous substances and could be further used as compost, it has been found that replenishment of nutrients in the used substrate (spent mushroom substrate) makes it recyclable for another cycle of mushroom production. The spent mushroom substrate from oyster 
mushroom production could be used for compost preparation for cultivation of button mushrooms. Ma et al., 2014; Royse et al., 2017).The SMS is which can be utilized as compost, and further used as substrate.

After addition of rice or wheat bran to spent substrate at $10 \%$ and $15 \%$, it can be used for oyster mushroom cultivation again and for preparation of compost from this waste manure from animal/ poultry farm is added as a source of nitrogen and the resulting compost is utilized for white button mushroom cultivation with proper disinfection treatments (Picornell Buendía et al., 2015).

\section{Training and economic support from government}

The government in support of cottage industries and rural development is promoting oyster mushroom cultivation. Several trainings are being organized by government bodies to educate rural people about mushroom farming techniques and marketing strategies. The government has also provided subsidies for establishment of production and processing unit.

National horticulture board (Gurugram, Haryana), National Horticulture Mission, Directorate of Mushroom Research (Solan, Himachal Pradesh), etc. extends support to those farmers and women who are willing to start small scale business in mushroom cultivation. The training programs are not only for mushroom production, but also for production of spawn. The spawn production has also risen as a potential business in the rural as well as peri-urban areas.

In todays' world, when everyone one is urging to become vegan, mushrooms have paved the way towards being vegetarian. Its farming can be started with low inputs and minimum skills, which makes it more suitable for rural areas. The popularity of its cultivation is not limited to villages, but the increasing demand in gourmet restaurants facilitated it to metro cities also. Now a days, non-agricultural people are also opting mushroom cultivation as a beneficial career than corporate world.

The people are now adopting oyster mushrooms to their routine diets, therefore, there is need to develop or identify or domesticate new species of Pleurotus and other mushrooms. Along with this technological advancement for substrate disinfection, processing and packing is required. This present review will certainly be helpful in understanding the importance of Pleurotus spp. and to focus on future research aspects.

\section{References}

1. Aguilar, C.H.M., Barbosa, J.R.M.I., Zapico, F.L. and Flamiano, R.S. 2010. Growth and yield performance of oyster mushroom (Pleurotus ostreatus) feeding on different agro-industrial wastes. UniversitiSains Malaysia Research and Development Journal, 18(1):18-30.

2. Ahmed, M., Abdullah, N., Ahmed, K.U. and Bhuyan, M. 2013. Yield and nutritional composition of oyster mushroom strains newly introduced in Bangladesh. Pesquisa Agropecuária Brasileira, 48:197 202.

3. Aida, F.M.N.A., Shuhaimi, M., Yazid, M., Maaruf, A.G., 2009. Mushroom as a potential source of prebiotics: a review. Trends Food Sci. Technol. 20, 567-575.

4. Badu M, Twumasi SK, Boadi NO (2011) Effect of lignocellulosic in wood used as substrate on the quality and yield of mushrooms. Food Nutr. Sci. 2:780-784.

5. Chang, S.T., Miles, P.G., 2004. Mushrooms: Cultivation, Nutritional Value Medicinal Effect and Environmental 
Impact. CRC Press, Boca Raton.

6. Eira, A.F., 2003. Cultivo do cogumelo medicinal. Editora Aprenda $\mathrm{Fa}^{\prime}$ cil, Vic sosa (in Portuguese).

7. Gil-Ramı'rez, A., Clavijo, C., Palanisamy, M., Ruiz-Rodrı'guez, A., Navarro-Rubio $\mathrm{Pe}^{\prime}$ rez, M. 2013. Study on the 3-hydroxy3- methyl-glutaryl CoA reductase inhibitory properties of Agaricus bisporus and extraction of bioactive fractions using pressurised solvent technologies. J. Sci. Food Agric. 93, 2789-2796.

8. Gume, B., Muleta, D. and Abate, D. 2013. Evaluation of locally available substrates for cultivation of oyster mushroom (Pleurotus ostreatus) in Jimma, Ethiopia. African Journal of Microbiology Research 7: 2228-2237.

9. Hussain, M., Khan, S.M., Khan, S.M., Chohan, M.A., 2002. Effect of different sterilization methods on the production of oyster mushroom (Pleurotus ostreatus) on different substrates. In: Integrated plant disease management. Proceeding of 3rd National Conference of Plant Pathology, NARC, Islamabad: 1-3 Oct. 2001, pp. 159-160.

10.Kalac, P., 2009. Chemical composition and nutritional value of European species of wild growing mushrooms: a review. Food Chem. 113, 9-16.

11.Kalac, P., 2013. A review of chemical composition and nutritional value of wildgrowing and cultivated mushrooms. J. Sci. Food Agric. 93, 209-218.

12.Knop, D., Yarden, O., Hadar, Y., 2015. The ligninolytic peroxidases in the genus Pleurotus: divergence in activities, expression, and potential applications. Appl. Microbiol. Biotechnol. 99, 10251038.

13.Li, X., Pang, Y., Zhang, R., 2001. Compositional changes of cottonseed hull substrate during $P$. ostreatus growth and the effects on the feeding value of the spent substrate. Bioresour. Technol. 80,
$157-161$

14.Mariga, A.M., Yang, W.J., Mugambi, D.K., Pei, F., Zhao, L., Shao, Y. 2014. Antiproliferative and immunostimulatory activity of a protein from Pleurotus eryngii. J. Sci. Food Agric. 94, 31523162.

15.Moda, E.M., Horii, J., Spoto, M.H.F., 2005. Edible mushroom Pleurotus sajorcaju production on washed and supplemented sugarcane bagasse. Sci. Agric. 62, 127-132.

16. Oei P (2005). Small scale cultivation of mushroom. AGRODOK series 40. Digigaf, Netherlands. Pp. 37-63.

17. Ortega, G.M., Martinez, E.O., Betancourt, D., Gonzale' z, A.E., Otero, M.A., 1992. Bioconversion of sugar cane crop residues with white-rot fungi Pleurotus sp. World J. Microbiol. Biotechnol. 8, 402-405.

18.Panjikkaran, S.T., Mathew, D., 2013. An environmentally friendly and costeffective technique for the commercial cultivation of oyster mushroom [Pleurotus florida (Mont.) Singer]. J. Sci. Food Agric. 93, 973-976.

19.Pant, D., Reddy, U.G., Adholeya, A., 2006. Cultivation of oyster mushroom on wheat straw and bagasse substrate amended with distillery effluent. World $J$. Microbiol. Biotechnol. 22, 267-275.

20.Pathmashini, L., Arulnandhy, V. and Wijeratnam, R.W. 2008. Cultivation of oyster mushroom (Pleurotus ostreatus) on sawdust. Ceylon Journal of Science 37: 177-182.

21.Pe'rez-Mart1'nez, A.S., Acevedo-Padilla, S.A., Bibbins-Mart1'nez, M., Galva' nAlonso, J., Rosales-Mendoza, S., 2015. A perspective on the use of Pleurotus for the development of convenient fungi-made oral subunit vaccines. Vaccine 33, 25-33.

22. Ragunathan, R., Swaminathan, K., 2003. Nutritional status of Pleurotus spp. grown on various agro-wastes. Food Chem. 80, $371-375$. 
23.Reddy, G.V., Babu, P.R., Komaraiah, P., Roy, K.R., Kothari, I.L., 2003. Utilization of banana waste for the production of lignolytic and cellulolytic enzymes by solid substrate fermentation using two Pleurotus species ( $P$. ostreatus and $P$. sajor-caju). Process Biochem. 38, 14571462.

24.Savoie, J.M., Salmones, D., Mata, G., 2007. Hydrogen peroxide concentration measured in cultivation substrates during growth and fruiting of the mushrooms. Agaricus bisporus and Pleurotus spp. J. Sci. Food Agric. 87, 1337-1344.

25.Sheu, F., Chien, P.J., Wang, H.K., Chang, H.H., Shyu, Y.T., 2007. New protein PCiP from edible golden oyster mushroom (Pleurotus citrinopileatus) activating murine macrophages and splenocytes. $J$. Sci. Food Agric. 87, 1550-1558.

26. Tesfaw A, Tadesse A, Kiros G (2015). Optimization of oyster (Pleurotus ostreatus) mushroom cultivation using locally available substrates and materials in Debre Berhan, Ethiopia. J. Appl. Biol. Biotechnol. 3(1):15-20.

27.Tikdari, M.M. and Bolandnazar, S. 2012. Application of organic nitrogen supplementations increases the yield of oyster mushroom (Pleurotus florida). Research in Plant Biology 2:10-15.

28.Xu, X., Yan, H., Chen, J., Zhang, X., 2011. Bioactive proteins from mushrooms. Biotechnol. Adv. 29, 667-674.

29. Yang, W., Guo, F. and Wan, Z. 2013. Yield and size of oyster mushroom grown on rice/wheat straw basal substrate supplemented with cotton seed hull. Saudi Journal of Biological Sciences 20:333338.

30. Yehia, R.S. 2012. Nutritional value and biomass yield of the edible mushroom Pleurotus ostreatus cultivated on different wastes in Egypt. Innovative Romanian Food Biotechnology 11:9-14.

31.Zhang, X., Wang, L., Ma, F., Yang, J., Su,
M., 2016. Effects of arbuscular mycorrhizal fungi inoculation on carbon and nitrogen distribution and grain yield and nutritional quality in rice (Oryza sativa L.). J. Sci. Food Agric. http://dx.doi.org/10.1002/jsfa.8129.

32.Zireva, D., Fanadzo, M. and Mashingaidze, A. 2007. Effect of substrate quantity and shelf position on yield of oyster mushroom (Pleurotus sajorcaju). Pakistan Journal of Biological Sciences 10:3458-3461.

33.Estrada AER, Jimenez-Gasco MM, Royse DJ (2009) Improvement of yield of Pleurotus eryngiivar. eryngii by substrate supplementation and use of a casing overlay. Bioresour. Technol 100:52705276.

https://doi.org/10.1016/j.biortech.2009.02. 073

34.Pardo-Giménez A, Zied DC, Álvarez-Ortí M, Rubio M, Pardo JE (2012) Effect of supplementing compost with grapeseed meal on Agaricus bisporus production. $J$ Sci Food Agric, 92(8):1665-1671. https://doi.org/10.1002/jsfa.5529

35.Pardo-Giménez A, Catalán L, Carrasco J, Álvarez-Ortí M, Zied D, Pardo J (2016) Effect of supplementing crop substrate with defatted pistachio meal on Agaricus bisporus and Pleurotus ostreatus production. J Sci Food Agric 96(11):38383845. https://doi.org/10.1002/jsfa.7579

36. Carrasco, J. Zied, D.C., Pardo, J.E., Preston, G.M. and Pardo-Giménez, A. (2018). Supplementation in mushroom crops and its impact on yield and quality, AMB Express, 8 (148), https://doi.org/10.1186/s13568-018-06780

37. Rebecca Jeyanthi, L, Seshiah C, Kowsalya E, Sharmila S (2015) Effect of food processing waste on the growth and nutrition quality of Pleurotus ostreatus. Int J Pharm Technol, 7(2):8887-8893.

38. Hoa HT, Wang CL, Wang CH (2015) The 
effects of different substrates on the growth, yield, and nutritional composition of two oyster mushrooms (Pleurotus ostreatus and Pleurotus cystidiosus). Mycobiology, 43(4):423-434. https://doi.org/10.5941/MYCO.2015.43.4. 423

39. Burton K, Noble R, Rogers S, Wilson J (2015) Understanding mushroom nutrition: project aimed at improving yield, substrate efficiency and utilisation and flavor. M056 Final Report. Agriculture and Horticulture Development Board (AHDB). p 54.

40.Zied DC, Savoie JM, Pardo-Giménez A (2011) Soybean the main nitrogen source in cultivation substrates of edible and medicinal mushrooms. In: El-Shemy HA (ed) Soybean and nutrition. InTech Open Access, Rijeka, pp 433-452.

41.Carrol AD Jr, Schisler LC (1976) Delayed release nutrient supplement for mushroom culture. Appl Environ Microbiol 31:499503.

42.Jadhav AC, Shinde DB, Nadre SB, Deore DS (2014) Quality improvement of casing material and yield in milky mushroom (Calo cybeindica) by using biofertilizers and different substrates. In: Proceedings of 8th international conference on mushroom biology and mushroom products (ICMBMP8). ICAR-Directorate of Mushroom Research, Solan, India. pp 359-364.

43.Pratiksha K, Narute TK, Surabhi S, Ganesh A, Sujoy S (2017) Effect of liquid biofertilizers on the yield of button mushroom. J Mycopathol Res, 55:135141.

44.Ma Y, Wang Q, Sun X, Wang X, Su W, Song N (2014) A study on recycling of spent mushroom substrate to prepare chars and activated carbon. BioResources 9(3):3939-3954.

45.Royse DJ, Baars J, Tan Q (2017) Current overview of mushroom production in the world. In: Zied DC, Pardo- Giménez A (eds) Edible and medicinal mushrooms: technology and applications. Wiley, Hoboken, pp 5-13. https://doi.org/10.1002/97811 19149 446.ch2

46.Picornell-Buendía MR, Pardo A, de Juan JA (2015) Reuse of degraded Pleurotus ostreatus substrate through supplementation with wheat bran and Calprozime ${ }^{\circledR}$ quantitative parameters. AgronColomb 33(2):261-270. https://doi.org/10.1111/jfq.12216

\section{How to cite this article:}

Vinita Rajput and Ravika. 2020. Upliftment of Rural Livelihood with Advanced Production Technology of Oyster Mushrooms. Int.J.Curr.Microbiol.App.Sci. 9(03): 1804-1813. doi: https://doi.org/10.20546/ijcmas.2020.903.209 